\title{
GEOTHERMAL WASTE TREATMENT BIOTECHNOLOGY
}

Eugene T. Premuzic and Mow S. Lin

BNL- -46301

DE91 014796

May 1991

Prepared for presentation at the International Conference - Heavy Metals in the Environment, Edinburgh, Scotland, September 16-29, 1991.

BIOSYSTEMS AND PROCESS SCIENCES DIVISION

DEPARTMENT OF APPLIED SCIENCE BROOKHAVEN NATIONAL LABORATORY ASSOCIATED UNIVERSITIES, INC. UPTON, NY 11973

Under Contract No. DE-ACO2-76CHOOO16 with the U.S. Department of Energy 


\section{DISCLAIMER}

This report was prepared as an account of work sponsored by an agency of the United States Government. Neither the United States Government nor any agency Thereof, nor any of their employees, makes any warranty, express or implied, or assumes any legal liability or responsibility for the accuracy, completeness, or usefulness of any information, apparatus, product, or process disclosed, or represents that its use would not infringe privately owned rights. Reference herein to any specific commercial product, process, or service by trade name, trademark, manufacturer, or otherwise does not necessarily constitute or imply its endorsement, recommendation, or favoring by the United States Government or any agency thereof. The views and opinions of authors expressed herein do not necessarily state or reflect those of the United States Government or any agency thereof. 


\section{DISCLAIMER}

Portions of this document may be illegible in electronic image products. Images are produced from the best available original document. 
E.T. Premuzic*, M. Lin"

\section{ABSTRACT}

Technical feasibility of a biotechnology based on biochemical reactions for detoxification of geothermal brines has been denonstrated. Laboratory-scale studies have shown that the emerging biotechnology is versatile and is applicable to a variety of geothermal sludges and materials with similar geochemical properties. Materials suitable for treatment ore those which may contain few or many metals in concentrations exceeding those allowed by regulatory agencies. Comparison of several possible types of bioreactors and processes have led to the conclusion that a number of variables have to be considered in the design and development of a biochemical plant for the detoxification of geothermal type sludges. These include reactor size, effects of agitation, mixed cul tures, state of the biomass. PH and dissolved oxygen, concentration of residual sludge, residence time, and temperature. Under optimum conditions, high rates of metal removal can be achieved. For example, 80-90\% removal efficiency has been reached for metals such as chromium, copper, and manganese. Some recent studies, dealing with the process variables and their optimization, will be discussed.

\section{INTROOUCTION}

For the past several years the geothermal research and development effort in this laboratory has been aimed at the development of biochemical prociesses for the treatment of wastes and by-products generated in the production of geothermal power (ref 1-3). The ultimate goal is to develop an environmentally acceptable, economically and technically feasible biotechnology for the removal and concentration of toxic metals present in the residual sludges associated with the power production. Such biotechnology is particularly useful when large quantities of wastes are present which contain low, however enviromentally significant concentration of metals, disposal of which is regulated. It has been shown that a number of process variables are essential and have to be considered in the design of biotreatment processes. For example, mixtures of selected strains of acidophilic bacteria in certain proportions are more efficient than each strain alone (ref 4). In addition to the increased efficiency of mixed cultures, several other parameters have to be considered. These include reactor size and type, mode of mixing, addition of biomass, $\mathrm{pH}$ and dissolved oxygen, sludge concentration and temperature. Development of thermoadapted acidophilic microorganisms has allowed to consider a process operating at $50-60^{\circ} \mathrm{C}$ and $\mathrm{pH} 1-2$. Under these operating conditions fast and highly efficient metal solubilization kinetics can be achieved. Currently two types of bioreactors, an agitated tank and a fluidized bed, are being considered and their applications optimized.

\section{OUTLINE OF STUDY AND MATERIALS}

Experimental procedures have been reported elsewhere (ref 3 ). In the present work analyses have been carried out in triplicate, both in solid and liquid phases. Two types of bioreactors have been constructed out of plastic materials (Plexiglas) for ambi ent and out of glass for elevated temperature studies. For sake of expedience, atomic adsorption was used in routine kinetic studies and limited to four representative metals, copper, zinc, manganese and lead. Detailed multielement analyses have also been carried out with an Induced Coupled Plasnie Mass Spectrometer (ICP-MS) VG-Plasma Quad 2 instrument. Four different concentrations of geothermal sludge, 10x, 20x, 30x and 40x have been used in the studies reported in this paper.

\section{RESULTS}

Interaction between microbial biomass and geothermal sludge involves an attachment of microorganisms to the substrate (ref 3) followed by enzymatic solubilization of metal salts. Therefore, for an efficient process, good mixing of the solid and liquid phases during the residence time is critical. Further, the biomass is pregrown and then mixed with the substrate in a bioreactor. In the present work two waste treatment plants have been considered, one using a fluidized bed and the other an agitated bioreactor. A process flow diagram for an agitated tank bioreactor system is shown in fig. 1. In this process, agitated tank and fluidized bed bioreactor are interchangeable. Processes using either bioreactor are similar, except that the fluidized bed bioreactor when replaced by an agitated tank allows for a process which requires a much smaller air supply. This is a significant costefficiency factor, because a large air compressor needed in the fluidized bed is replaced by a cheaper stirrer used in the agitated tank. Details of the cost analyses have been discussed elsewhere (ref 5). The process shown in fig 1 is designed to handle 80,000 lb/day of geothermal waste contained in a $65 \%$ filter press cake generated by a $50 \mathrm{~m}$ double flash plant. The initial sludge is sent from a brine solid separation plant to the bioreactor via a conveyer belt at an average rate of 123,000 lb/day. Preliminary analyses of the processes shown in fig 1 have shown that the biotreatment is economically and technically feasible (ref 5 ). In the process, stream 1 and 2 are mixed in the bioreactor. The bioreactor outflow (stream 4) is sent to a filter press where it is concentrated into a solid cake which is the non-hazardous sol id waste product. At this stage, if the sol id product still exceeds regulated concentrations of toxic metsls, it can be recycled to the geothermal sludge holding tank (stream 5) and reprocessed. The liquid which passes through the filter press (stream 3 ) can be 


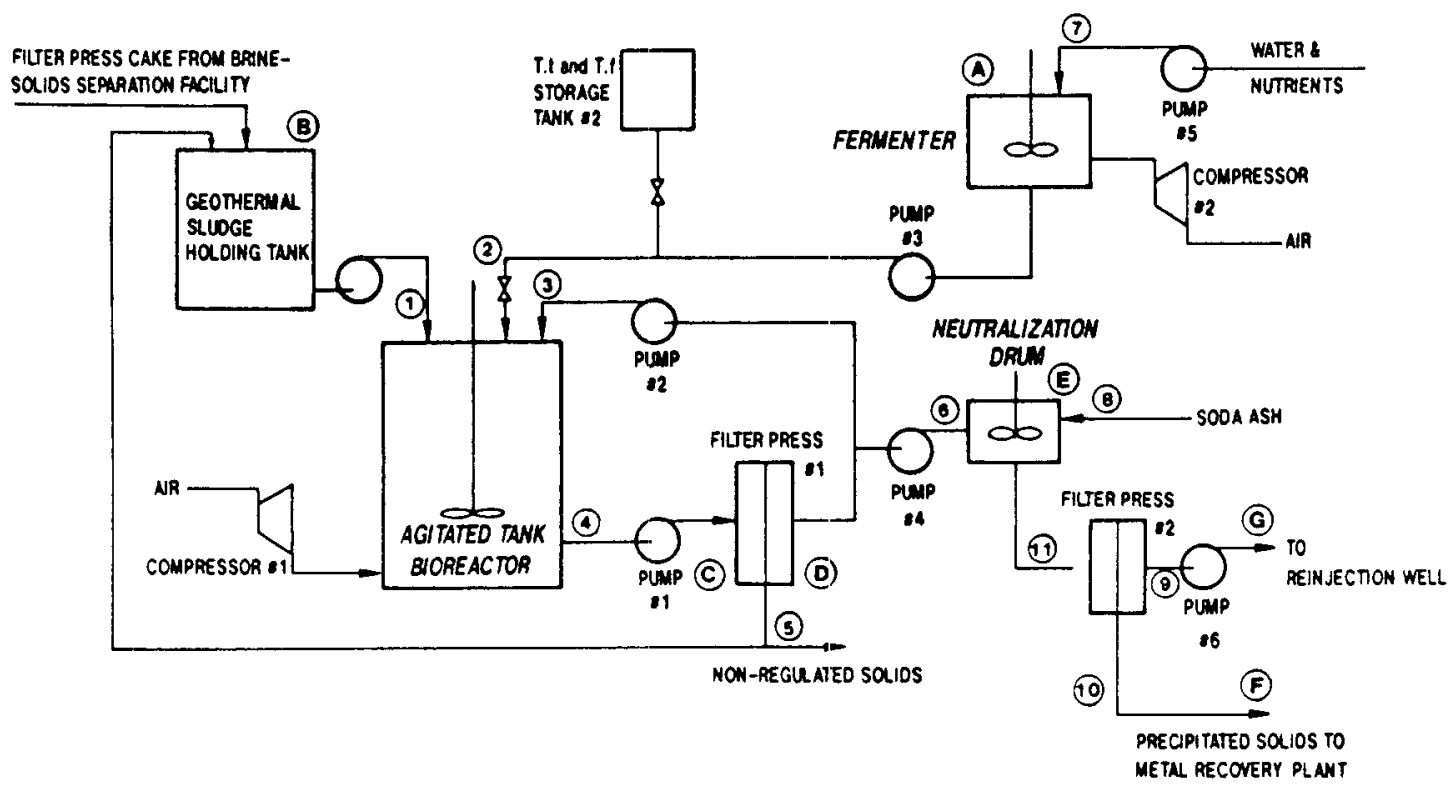

Fig. 1 Process flow diagran for biochennical waste-treatment plant.

recycled or be sent to a neutralization drum (stream 6) at $\mathrm{pH}-4$. The liquid is then pumped through another filter to collect any precipitated solids and bacteria from the neutralization step. The filtrate from press 2 is then pumped down a re-injection well (strean 9). The solids at filter press 2 may be sent to a metal recovery plant.

The effects of sludge loading and temperature on residence time are shown in fig 2 for copper. An 80\% removal of copper is achieved in 25 hours in either the fluidized bed or agitated tank bioreactor. The overall efficiency applies to other metals as shown in fig 3 . The results of kinetic studies show

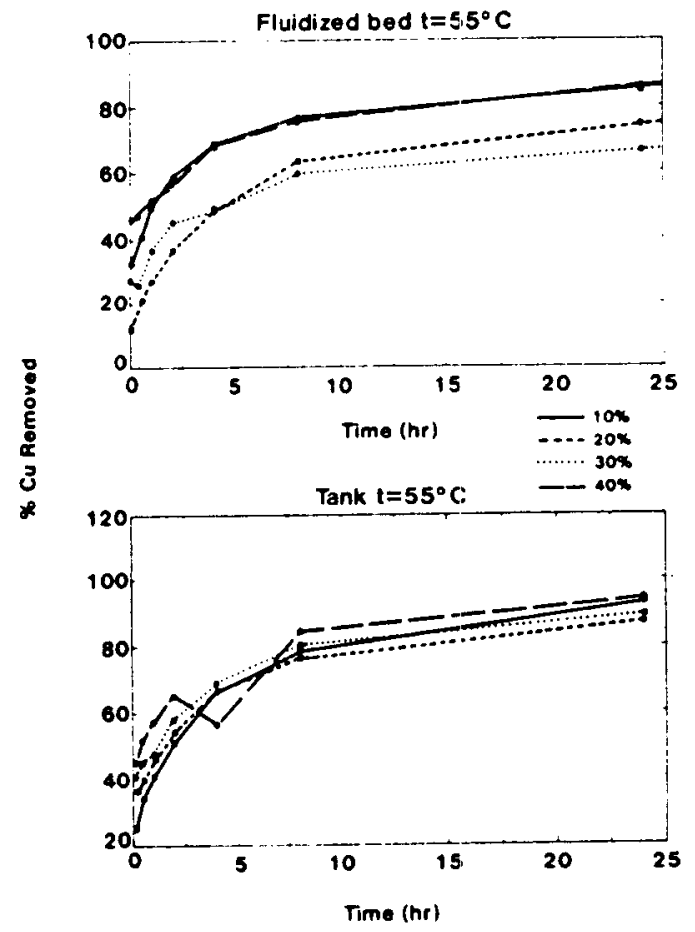

Fig. 2 Rates of removal of copper using fluidized and tank type bioreactors at $55^{\circ}$ and different sludge concentration. 


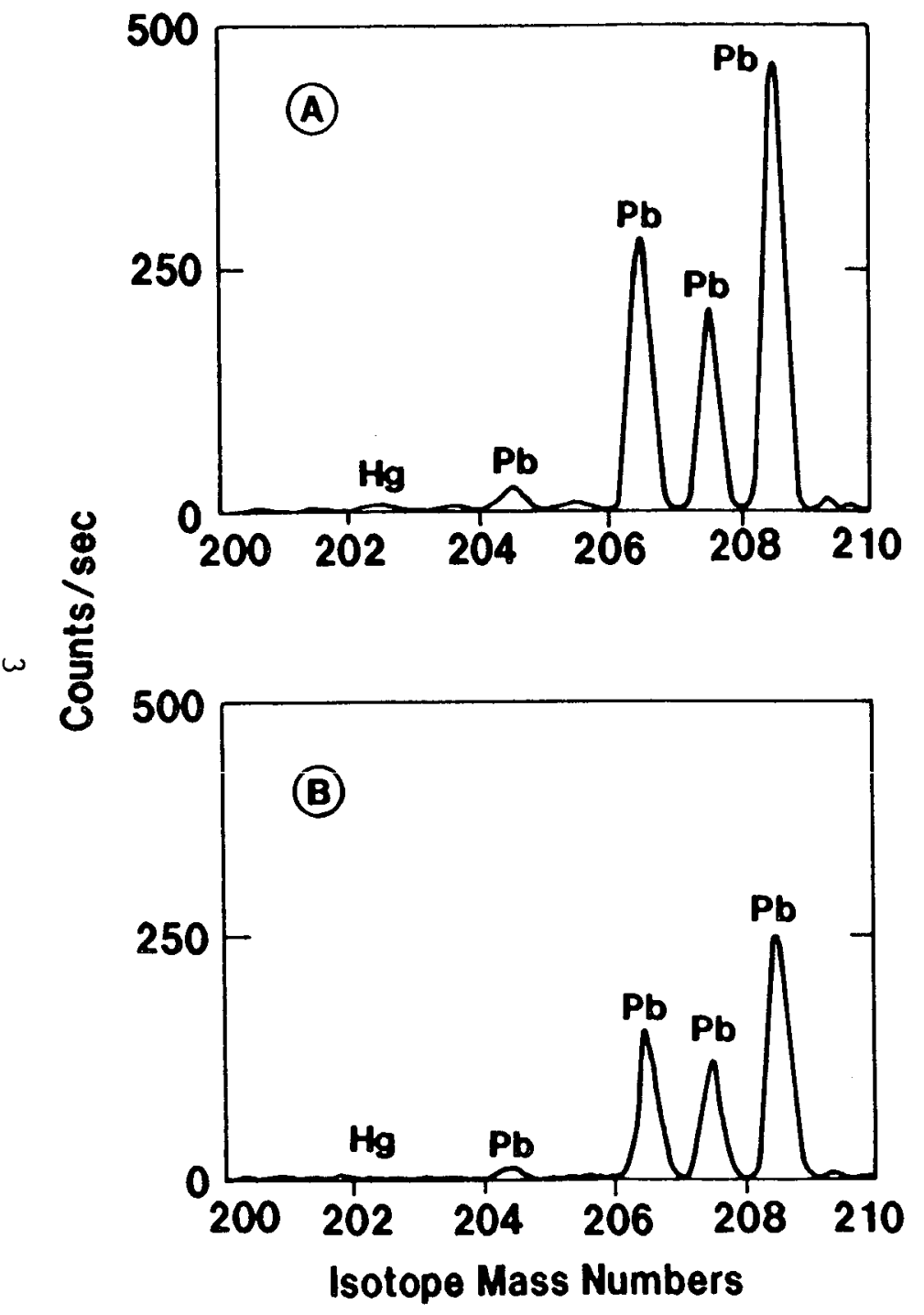

Fig. 3 ICP-MS analysis geothermal sludge. of mercury and lead contents in
A untreated, B treated.

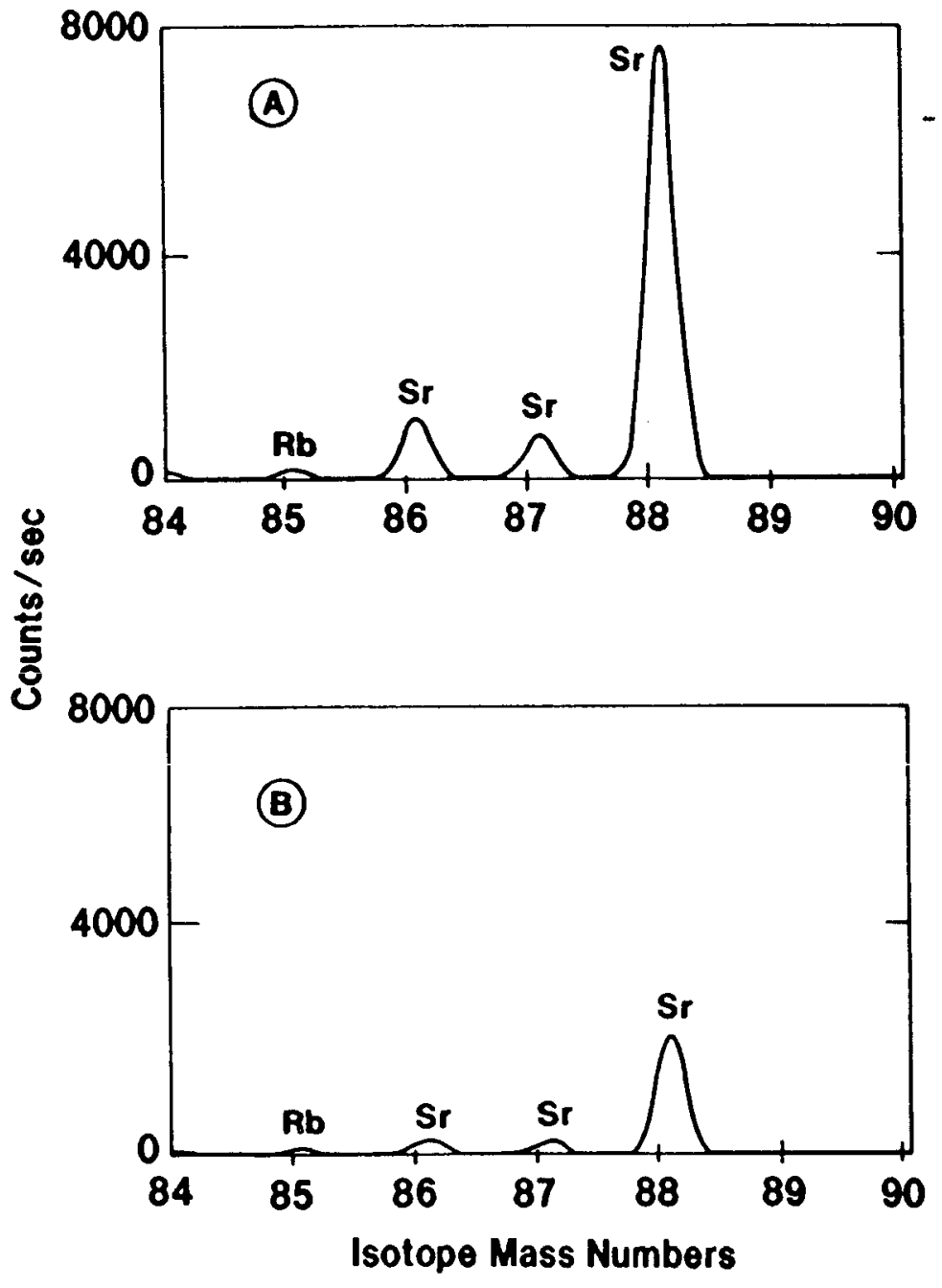

Fig. 3 ICP-MS analysis of rubidium and strontium contents in geothermal sludge. A untreated, $B$ treated. 
that there is an initial rapid removal of metals, followed by a drop, suggesting that several biochemical mechanisms are involved. From a process dasign point of view the initial rapid phase is important because it removes most metals to levels below the total regulated threshold limiting concentrations (ref 6) within a biotreatment period of 25 hours. Concurrent studies in this laboratory are also considering the metal option recovery (ref is) which may become an integral part of the detoxification process, both for enviromental and economic reasons. The emerging biotechnology is promising and is sufficiently flexible that it may be applied to similar materials of geological origin. Optimization of process variables will further improve on the efficiency of metal renoval. Because of temperature and acidity factors, materials to be used in the construction of bioreactors and other key components of a biotreatment plant are being considered in the continuing phases of this R\&D effort.

\section{ACKNOWLEDGMENTS}

This work has been sponsored by the U.S. Department of Ervergy, Division of Geothermal Technology, under Contract No. AM-35-10 and by Brookhaven National Laboratory and the U.S. Department of Energy under Contract NO. DE-ACO2-76CHOOO16.

\section{REFERENCE:}

1. E T Premuzic, M Lin, The Role of Biotechnology irı the Treatment of Geothermal Residual Sludges, Seventh International Conference on "Heavy Metals in the Environment," Proceedings, 2, 60-63 (1989).

2. E T Premuzic, M S Lin and S K Kang, Developments in Geothermal Waste Treatment Biotechnology, Proceeding VIII, Geothermal Program Review, Colf-9004131, 41-47 (1990).

3. E T Premuzic, M S Lin, L E Kukacka, and R D Sproull, Applications of Biotechnology in the Removal of Toxic Metals from Geothermal Residual Sludges, Geothermal Sci. Tech. 2(3), 139-160 (1990).

4. E T Premuzic and M S Lin, Patent Pending 1991.

5. E T Premuzic, M S Lin, S Kang, Advances on Geothermal Waste Treatment Biotechnology, in press, Conference Proceedings, Geothermal Program Review IX, CONF-913105, 77-84 (1991).

6. B A Royce, An Analysis of Enviromental Regulations Governing the Disposal of Geothermal Haste in Californie, BNL Report 37577 (1985).

\section{DISCLAIMER}

This report was prepared as an account of work sponsored by an agency of the United States Government. Neither the United States Government nor any agency thereof, nor any of their employees, makes any warranty, express or implied, or assumes any legal liability or responsibility for the accuracy, completeness, or usefulness of any information, apparatus, product, or process disclosed, or represents that its use would not infringe privately owned rights. Reference herein to any specific commercial product, process, or service by trade name, trademark, manufacturer, or otherwise does not necessarily constitute or imply its endorsement, recommendation, or favoring by the United States Government or any agency thereof. The views and opinions of authors expressed herein do not necessarily state or reflect those of the United States Government or any agency thereof. 